\title{
Efficacy, toxicity, and lethality of plants with potential anthelmintic activity in small ruminants in Brazil
}

Eficácia, toxicidade e letalidade de plantas com potencial atividade anti-helmíntica em pequenos ruminantes no Brasil

MOTTIN, Vanessa Daniele ${ }^{1}$; CRUZ, Jurandir Ferreira da ${ }^{2}$; TEIXEIRA NETO, Milton Resende $^{3}$; MARISCO, Gabriele ${ }^{4 ;}$ FIGUEREDO, Jennifer Souza ${ }^{1}$; SOUSA, Lorena Silva ${ }^{1}$

${ }^{1}$ Pós-Graduação em Zootecnia, Universidade Estadual do Sudoeste da Bahia. Estrada Itapetinga-Itambé, Km 4, CEP 45.700-000, Itapetinga - Bahia, Brazil.

${ }^{2}$ Universidade Estadual do Sudoeste da Bahia, Departamento de Fitotecnia e Zootecnia. Estrada do Bem Querer, Km 4. CEP 45083-900, Vitória da Conquista - Bahia, Brazil.

${ }^{3}$ Colegiado de Medicina Veterinária, Faculdade de Tecnologia e Ciência, Rua Ubaldino Figueira, 200, CEP 45.020-510, Vitória da Conquista - Bahia, Brazil.

${ }^{4}$ Universidade Estadual do Sudoeste da Bahia, Departamento de Biologia Geral. Estrada do Bem Querer, Km 4. CEP 45083-900, Vitória da Conquista - Bahia, Brazil.

\section{SUMMARY}

The use of medicinal plants as a therapeutic method in the control of diseases has been increasing in animal production. In the case of small ruminants, the endoparasitic disease is a major concern, since they are considered the greater sanitary problem, especially when considering the phenomenon of parasite resistance to the medicines used. Therefore, the development of alternative methods of endoparasitary control in goats and sheep has become a pressing need. The use of plants to control endoparasites can reduce the use of chemical inputs, making more environmentally sustainable livestock, minimizing the occurrence of parasitic resistance to conventional medicines and contributing to the reduction of production costs. In this sense, several studies have been carried out in order to evaluate the in vitro and in vivo activity of plants with anthelmintic potential. However, despite the potentiality found in many studies, the results are sometimes contradictory or do not replicate in vivo the same efficacy obtained in the in vitro assays. Another relevant aspect is the low utilization of the lethality and toxicity tests, which are indispensable so that the knowledge can be spread and applied by the producers in their herds. Thus, this review aims to provide the results from studies carried out in Brazil with extract of plants with potential for control of parasitic disease in goats and sheep, describing the main evaluated plants species, mechanisms of action, preparation forms and tests of efficacy, toxicity, and lethality.

Keywords: antiparasitics, biological assays, goat, medicinal plants, sheep

\section{RESUMO}

A utilização de plantas medicinais como método terapêutico no controle de enfermidades tem sido crescente na produção animal. No caso de pequenos ruminantes, as verminoses representam uma grande preocupação, visto que são consideradas o maior problema sanitário, especialmente quando se considera $\mathrm{o}$ fenômeno da resistência dos parasitas aos fármacos utilizados. Portanto, $\mathrm{o}$ desenvolvimento de métodos alternativos de controle endoparasitário em caprinos e ovinos tem se tornado uma necessidade premente. $\mathrm{O}$ uso de plantas para controlar as endoparasitoses pode reduzir o uso de insumos químicos, tornando a atividade pecuária mais ambientalmente sustentável, minimizando a ocorrência da resistência parasitária aos medicamentos convencionais e contribuindo para redução dos custos de produção. Nesse sentido, 
diversos estudos têm sido executados a fim de se avaliar a atividade in vitro e in vivo de plantas com potencial anti-helmíntico. Contudo, a despeito da potencialidade verificada em muitos estudos, os resultados são, por vezes, contraditórios ou não reproduzem in vivo a mesma eficácia obtida nos ensaios in vitro. Outro aspecto relevante é a baixa utilização dos testes de letalidade e toxicidade, indispensáveis para que o conhecimento possa ser difundido e aplicado pelos produtores rurais. Assim, essa revisão visa fornecer os resultados obtidos nos estudos realizados no Brasil com extratos de plantas com potencial para controle de verminose em caprinos e ovinos, descrevendo as principais espécies vegetais avaliadas, mecanismos de ação, formas de preparo e os testes de eficácia, toxicidade e letalidade.

Palavras-chave: antiparasitários, ensaios biológicos, caprinos, plantas medicinais, ovinos 


\section{INTRODUCTION}

Small ruminant husbandry in Brazil has increased and contributes to the maintenance of small family-managed rural properties. The most recent agricultural census conducted in 2017 counted 8,252,706 goats and 13,770,344 sheep distributed in all states, with the largest herd recorded in the northeast region (SIDRA-IBGE, 2018).

The production and consumption of goat-sheep products should expand because of not only the natural growth of the population but also the organizational trend in the sector, which has great economic potential (Souza et al., 2016). However, challenges such as diseases can limit or economically harm sheep and goat husbandry (Sprenger et al., 2015).

Parasitism is a major factor limiting livestock production in general. The goat and sheep industry are affected by many parasites representing significant losses in meat, milk and wool culture (Ataide and Cansi, 2013). Notwithstanding the availability of alternative methods to control and treat parasitic diseases (Molento et al., 2011), allopathic drugs remain the main choice for this purpose (Melo et al., 2015; Costa et al., 2017).

World trade in animal health drugs reached US \$30 billion in 2016 (Statista, 2018), with an upward projection of expenditures estimated at US \$54 billion/year by 2027 (FMI, 2017). In Brazil, the industry net billing in this sector in 2017 was approximately US $\$ 1,4$ billion, of which $27,2 \%$ was related to trade in antiparasitic products (SINDAN, 2018).

The indiscriminate use of antiparasitic drugs is associated with the high resistance currently observed in parasites, which can cause great economic losses as it reduces animal productivity and increases costs following non-effective treatments (Molento et al., 2013).

Studies of plants with antiparasitic medicinal potential have been seeking to reduce treatment costs and environmental contamination (Eguale et al., 2007). Assays using plant extracts have shown satisfactory results in reducing endoparasitism (Rodrigues et al., 2007; Peneluc et al., 2009, Silva et al., 2010). Phytochemical studies, which involve isolation of plant extract constituents with anthelmintic potential (Cordeiro et al., 2010), are a valuable initial step in determining the in vitro efficacy and toxicity followed by in vivo evaluations (Andrade et al., 2014). This review aims to provide the results from studies carried out in Brazil with extract of plants with potential for control of parasitic disease in goats and sheep, describing the main evaluated plants, mechanisms of action, preparation forms and tests of efficacy, toxicity, and lethality.

\section{METHODOLOGY}

For the accomplishment of this review, scientific articles related to plants with anthelmintic potential in goats and sheep were searched in six scientific portals: Google Academic, Capes Periodicals, Lilacs, Scielo, Pubmed and Science Direct journals. The following keywords were used: extracts, plants, antihelmintics, anti-parasites, goats, sheep, Brazil. Publications were searched in Portuguese, English, and Spanish from 2000 to 2018. Articles with biological assays (in vivo and / or in vitro) were considered; duplication articles, undergraduate studies, theses, dissertations, reviews, and works presented in events were used as exclusion criteria. From these criteria, 
48 articles were selected to form the basis of this review.

\section{MAIN PLANTS EVALUATED FOR ANTHELMINTIC EFFECT IN SMALL RUMINANTS AND MECHANISM OF ACTION OF THEIR ACTIVE FRACTIONS}

Many plant species have been studied to verify their anthelmintic effects in Brazil. Among the 50 plants listed in this study (Figure 1), Operculina halmiltonii is the most widely studied species (8.6\%), followed by Mormodica charantia, Musa sp., Azadirachta indica, Agave sisalana, and Allium sativum. These plants are also found in other countries (Zhang et al., 1996, Hammel, 2010, Davidse et al., 2012, Karuppiah and Mustaffa, 2013, Wang et al., 2014), and many of them have been the subject of research in this field (Fang et al., 2007, Karuppiah and Mustaffa, 2013, Wang et al., 2014).

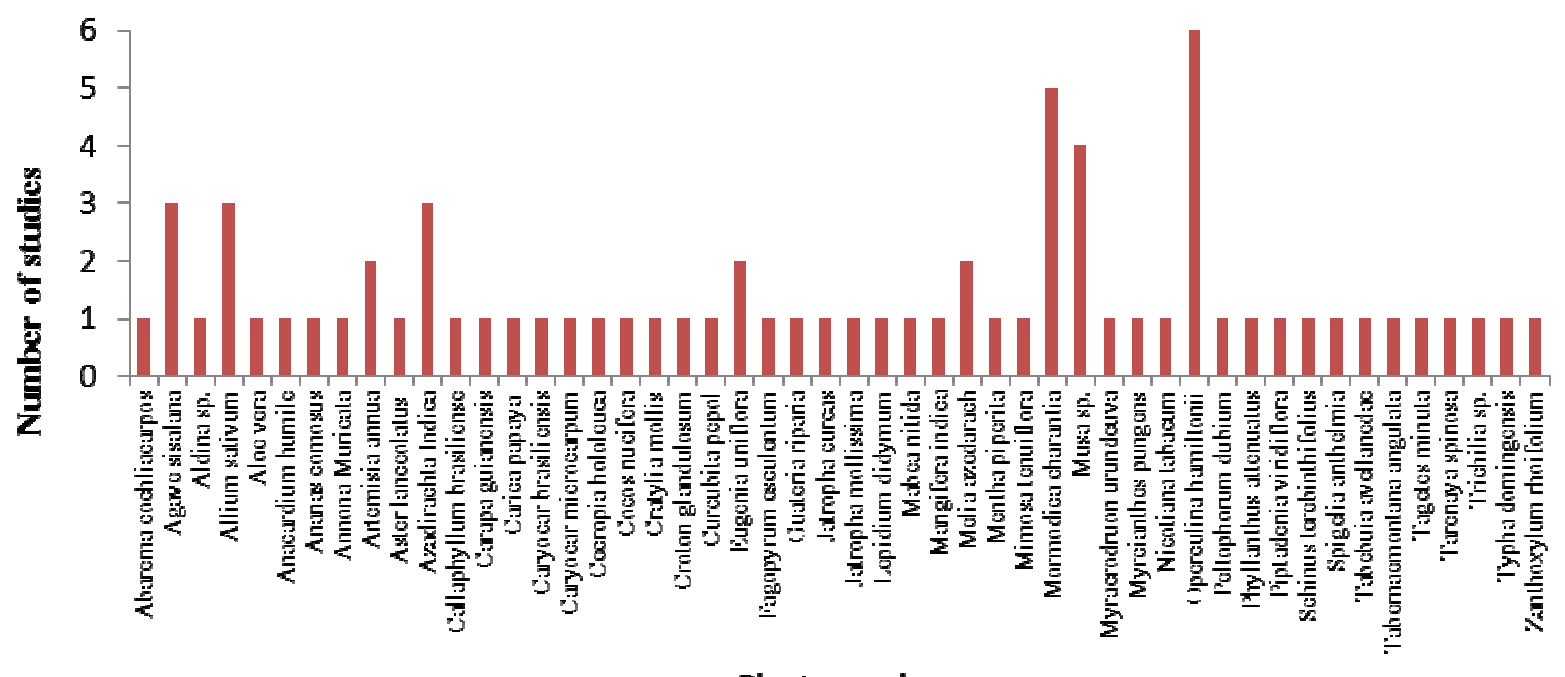

Plants specles

Figure 1. Number of studies of plants with anthelmintic activity in goats and sheep carried out in Brazil, from 2000 to 2018

Operculina halmiltonii, commonly found in the North and Northeast regions of Brazil (Braga, 1960), has shown mixed results in antiparasitic efficacy tests (Almeida et al., 2007; Rodrigues et al., 2007; Gomes et al., 2010; Silva et al., 2010; Araújo et al., 2011; Brito-Júnior et al., 2011). The anthelmintic activity of this plant is attributed to the presence of condensed tannins in its composition (Silva et al., 2010, Nogueira et al., 2012), which may act by expelling parasites or reducing female fecundity (Shalders et al., 2014).
Condensed tannins promote adherence between the extract and larvae, preventing its motility and feeding, resulting in energetic stress and death of the parasite (Gomes et al., 2010). The interaction with the proteins of the cuticle, oral cavity, esophagus, cloaca, and vulva of the nematodes are described as tannins direct actions. While reducing the amount of digested protein in the rumen and increasing its availability in the small intestine, favoring the host's antiparasitic immune response, are described as indirect 
actions of these metabolites (Hoste et al., 2006). The use of a tannin inhibitor, such as polyvinylpyrrolidone, together with plant extracts with known anthelmintic action, was able to reduce the activity of the product, thus demonstrating the real anthelmintic effect attributed to the tannins (Oliveira et al., 2011).

The antihelminthic effect of Mormodica charantia has been evaluated previously in caprine species (Almeida et al., 2007; Cordeiro et al., 2010; Gomes et al., 2010; Brito-Júnior et al., 2011) and showed contrasting results. These differences may be due to the plants used in the studies presenting active ingredient in different concentrations since they came from regions with different edaphoclimatic conditions (Furtado et al., 2013). The triterpene glycosides and mormodicins I and II are main secondary metabolites responsible for nematicidal action (Beloin et al., 2005), although tannins are abundant in this plant extract (Gomes et al., 2010). The interaction of several chemical groups on different compounds may enable activity toward multiple molecular targets at different stages of parasite development (MarieMagdeleine et al., 2009).

Musa sp. has been the subject of several studies showing contrasting results (Oliveira et al., 2010; Parra et al., 2011; Silva et al., 2013; Gregory et al., 2015). These differences may be because different parts of the plant were used and/or the soil and climate conditions differed during the sampling period (Furtado et al., 2013). Phytochemical analyses showed that the banana pseudoculm contains polyphenolic compounds, including tannins (Lans et al., 2000), which were previously described as anthelmintic agents (Gomes et al., 2010; Shalders et al., 2014).
Azadirachta indica, which is native to the arid regions of India (Saxena, 1983), is another plant that has presented contradictory results regarding its anthelmintic action (Igarashi et al., 2013; Salas et al.; 2013, Soares Filho et al., 2015). This is likely attributed to the different concentrations of azadirachtin in the analyzed extracts. Azadirachtin, responsible for the anthelmintic effect of $A$. indica, is highly sensitive to ultraviolet radiation and acidic and alkaline media, which allow its rapid biodegradation (Neves et al., 2003). Different parts of the plants can also be a source of variation, since its present varying levels of fatty acids and metabolites associated with a nematicidal action (Salas et al., 2013). The substances contained in A. indica affect parasite feeding, growth, longevity, and fertility - interfering with copulation behavior, oviposition, and egg viability (El-Shafie and Basedow, 2003; Hasan and Ansari, 2011).

The antihelminthic effect of Agave sisalana was studied in goats (Domingues et al., 2010; Botura et al., 2011; Silveira et al., 2012) and sheep (Silveira et al., 2012) but these studies showed discordant results. Agave sisalana contains saponins as secondary metabolites (Francis et al., 2002). Saponins exhibit surfactant activity and form a stable foam when shaken with water, a phenomenon that can affect eukaryotic organisms, which contain steroids in their membranes (Osbourn, 1996). Agave sisalana is very socioeconomically important for fiberproducing municipalities in the Brazilian semi-arid region (Santos, 2006).

Allium sativum is a plant contains allicin which has anthelmintic effects. However, allicin is very unstable (Santos et al., 2011); this may explain the contradictory results obtained in 
previous studies (Almeida et al., 2004; Santos et al., 2011, Holsbach et al., 2013). Allicin acts on the integument of the parasite causing edema and ulcerations, which, consequently, promote greater exposure of the antigens, rendering it more vulnerable to the host's immune system (Lima et al., 2011).

Melia azedarach showed satisfactory endoparasite control results when extracts (ethanolic) were prepared from seeds and leaves (Maciel et al., 2006), in contrast to extracts prepared with the fruit in natura (Falbo et al., 2008). The phytochemical profile of the leaves and seeds indicated the presence of condensed tannins, triterpenoids, steroids, and alkaloids, which are associated with anthelmintic actions. Notably, the seed extract had a greater effect on egg hatchability, whereas the leaf extract was more effective in inhibiting larval development, suggesting that the leaves and seeds contain compounds with different chemical structures (Maciel et al. al., 2006).

Artemisia annua has shown contradictory efficacy in recent research using leaf extract in sheep (Cala et al., 2014; Sprenger et al., 2016). Studies to identify the metabolites responsible for the anthelmintic action revealed the presence of alkaloids, catechins, steroids, phenols, resins, tannins, and triterpenes (Sprenger et al., 2016).

\section{PREPARATION FORMS OF PLANTS FOR USE AS ANTHELMINTICS}

To evaluate anthelmintic effects, the plants have been prepared using different methods, with most (77\%) studies using plant extracts. Most studies using alcoholic and hydroalcoholic extracts were conducted in vitro, while studies using aqueous extracts were performed in vitro and in vivo assays. When using the plants in natura, all studies were performed in vivo (Table 1).

The extraction process, which enables concentration of active principles (Coêlho et al., 2017), is divided into two stages: i) removal of the secondary metabolites from the plant using solvents and ii) evaporation of the extraction components (Santos, 2013). Although the extractive preparation methodology is relatively standardized, the substances used in the extraction process directly influences the extract yield and content of the final product (Xynos et al., 2012; Oliveira et al., 2016).

Table 1. Methods of preparation, number of studies, and evaluation types of plants with anthelmintic potential in goats and sheep, from 2000 to 2018

\begin{tabular}{|c|c|c|c|c|c|}
\hline \multirow{2}{*}{ Preparation methods } & \multirow{2}{*}{$\begin{array}{l}\text { Number of } \\
\text { studies }\end{array}$} & \multicolumn{4}{|l|}{ Evaluation type } \\
\hline & & $\begin{array}{l}\text { In vitro evaluation } \\
(\%)\end{array}$ & $\begin{array}{lll}\text { In } & \text { vivo evaluation } \\
(\%) & & \\
\end{array}$ & $\begin{array}{l}\text { Joint } \\
(\%)\end{array}$ & evaluation \\
\hline Aqueous extracts & 20 & 42,5 & 37,25 & 20,25 & \\
\hline Alcoholic extracts $*$ & 13 & 69.24 & 15.38 & 15.38 & \\
\hline Hydroalcoholic extracts & 8 & 75.0 & 12.5 & 12.5 & \\
\hline Other extracts & 10 & 70.0 & 10.0 & 20.0 & \\
\hline Fresh & 5 & 0 & 100 & 0 & \\
\hline Oil & 5 & 66.66 & 33.34 & 0 & \\
\hline Other preparations & 5 & 20.0 & 80.0 & 0 & \\
\hline
\end{tabular}

* Prepared with ethanol, except for one, in which methanol was used as extractive agent. 
Egg hatchability and/or larval development was reduced by more than $80 \%$ in $88,88 \%$ aqueous extracts under in vitro conditions for at least one of the concentrations used (Nery et al., 2010; Oliveira et al., 2010; Ferreira et al., 2013; Salas et al., 2013; Cunha et al., 2014; Morais Costa et al., 2016). No aqueous extracts showed an RFEC (reduction faecal egg count) greater than $80 \%$ under in vivo conditions; however, $71.42 \%$ of the extracts had RFEC of 50-80\% (Rodrigues et al., 2007; Botura et al., 2011; Domingues et al., 2013; Pereira et al., 2013; Silva et al., 2013; Mendonça-Lima et al., 2016; Coêlho et al., 2017). Only $25 \%$ of the aqueous extracts evaluated simultaneously in vitro and in vivo showed satisfactory results in both condition, with a reduction of up to $95 \%$ and $92 \%$, respectively (Peneluc et al., 2009). Other studies reported a $90 \%$ to $100 \%$ reduction of infecting larvae in vitro; however, the RFEC was 53\% (Nery et al., 2012), 47.20\% (Morais Costa et al., 2016), and 33\% (Nogueira et al., 2012). All alcoholic extracts evaluated in vitro showed promising effects (Assis et al., 2003; Almeida et al., 2004; Cordeiro et al., 2010; Gomes et al., 2010; Nery et al., 2010; Araújo et al., 2011; Sprenger, 2015; Tenório et al., 2015a; Morais Costa et al., 2016). Under in vivo condition, just alcoholic extract of $O$. hamiltonii showed satisfactory results (Brito-Júnior et al., 2011). The alcoholic extracts used in double trials, despite having shown an in vitro effect, were not effective in vivo (Cala et al., 2014; Ribeiro et al., 2014).

Only the hydroalcoholic extracts of Eugenia uniflora (Hassum et al., 2013; Gonçalves et al., 2016; Sprenger et al., 2016) and Artemisia annua (Sprenger et al., 2016) used in vitro assays showed promising results. Under in vivo condition, hydroalcoholic extracts of
Mormodica charantia and Lepidium didymum showed significant RFEC (Coêlho et al., 2017), while hydroalcoholic extract of Tarenaya spinosa showed phytotherapeutic potential for controlling gastrointestinal nematodes in vitro and in vivo assays (Andrade et al., 2014).

Other substances such as ethyl acetate (Assis et al., 2003; Oliveira et al., 2009), hexane (Assis et al., 2003; Maciel et al., 2006; Krychak-Furtado et al., 2011), chloroform (Assis et al., 2003; Maciel et al., 2006), acetone (Oliveira et al., 2011), dimethyl sulfoxide (Cunha et al., 2014), and dichloromethane (Cala et al., 2014) have been used as extractive agents.

Other forms of plant preparation used to evaluate the anthelmintic effect in small ruminants were: i) dehydrated leaves (Parra et al., 2011; Gregory et al., 2015) and ground (Falbo et al., 2008) and ii) dehydrated and ground fruit (Falbo et al., 2008) and juices (Almeida et al., 2004; Domingues et al., 2010; Santos et al., 2011). Using in natura plants, only Curcubita pepol showed an RFEC above $80 \%$ (Almeida et al., 2007). Oils extracted from two plants, Carapa guianensis (Farias et al., 2010) and Aster lanceolatus (Krychak-Furtado et al., 2011) showed anthelmintic effect.

Thus, although the extraction process is considerably more laborious, it is advantageous compared to the use of in natura plants. The extraction process may facilitate release of chemical components or active principles not released when the in natura plant is subjected to the digestion process (Coêlho et al., 2017).

EVALUATION OF THE EFFECTS
OF TOXICITY AND LETHALITY
OF PLANTS WITH POTENTIAL
ANTHELMINTIC EFFECT

EVALUATION OF THE EFFECTS OF TOXICITY AND LETHALITY ANTHELMINTIC EFFECT 
Toxicity and lethality tests are designed to measure the relative toxicity of substances and prevent undesirable effects in biological systems when the plants are used therapeutically (Forbes and Forbes, 1994; Silva et al., 2016). Despite the importance of this procedure, only $18 \%$ and $8 \%$ of the studies described in this review evaluated toxicity and lethality effects, respectively.

Toxicity is defined as an inherent property of the substance which exerts harmful effects on exposed organisms during a period at a defined concentration (Dux and Stalzer, 1988). Toxicity tests in animals can evaluate the general disposition, motor coordination, muscle tone, reflexes, and activity of the autonomic nervous system (Cunha et al., 2013), as well as hematological and biochemical alterations (Soares Filho et al., 2015). Likewise, there are trials that determine the reproductive toxicity of substances on mating rates, gestation, birth rate, offspring viability, weaning rate and embryo losses (Hollenbach et al., 2015); a specific test (Hershberger's test) can identify substances with androgenic and antiandrogenic activity (SEP, 2011). In post-mortem examinations, these tests are still able to verify macroscopic (Hayes and Dipasquale, 2001) and microscopic alterations in affected systems and organs (Tokarnia et al., 2012).

Two plants, among those described in this review, were subjected to toxicological testing in mice. Piptadenia viridiflora administered for 4 days at a dose of $203 \mathrm{mg} / \mathrm{kg}$ caused no behavioral nor organic changes (Morais-Costa et al., 2016). The extract of Cocos nucifera did not show toxicity following oral administration (Oliveira et al., 2009).
The toxic effects of seven plants were evaluated concurrently with the anthelmintic efficacy assays in the same animals. With Agave sisalana, the animals were evaluated for hepatic, renal, and physiological parameters and showed normal results except for hematocrit and hemoglobin, which showed values below normal (Domingues et al., 2010; Botura et al., 2011). Jatropha curcas, Tabebuia avellanedae, and Schinus terebinthifolius did not change the heart rate, respiratory rate, rectal temperature, and most hematological parameters. Only $J$. curcas reduced hematocrit and total protein levels (Wolupeck et al., 2012). Azadirachta indica did not show alterations in globular volume, total plasma protein, total leukocytes, segmented neutrophils, lymphocytes and eosinophils, creatinine, or aspartate aminotransferase (Soares Filho et al., 2015). Zanthoxylum rhoifolium did not change the clinical and biochemical parameters nor reveal changes suggestive of histopathological toxicity (Peneluc et al., 2009). There was also no toxic reaction in animals treated with bromelain extracted from Ananas comosus (Domingues et al., 2013).

The advances and contributions obtained by using animals in experiments are widely known. However, bioethical guidelines must be followed to limit the suffering of experimental animals (Lolas, 2008; Franco et al., 2014). Many animal evaluations can be performed using other test systems that provide similar efficiency (Fiskesjö, 1985).

The toxicity of a plant can be evaluated in vitro with relative ease by using Allium cepa. In this test, the effect of the toxic substance is observed by macroscopic alterations such as color, shape, size and root deformity, as well as microscopic changes such as 
chromosomal aberrations and mitotic index (Longhin, 2008; Arrares and Longhin, 2012). Assays with A. cepa are easy, fast, and reliable, (Arrares and Longhin, 2012), and highly correlated with other test systems, including mammalian animals (Fiskesjö, 1985). Notably, no plants described in this review were subjected to the $A$. серa assay.

Lethality is an effect that can be evaluated in animal tests to classify and catalog substances according to their lethal potential (Valadares, 2006). The signs that precede death, lethality index, mechanisms of action of the principles (Hayes and Dipasquale, 2001), and lesions observed in post-mortem histological examinations are parameters that can be observed in the lethality test (Tokarnia et al., 2012).

Only one plant described in this review was evaluated for lethality. In this study, Cocos nucifera extract was administered intraperitoneally to mice, and an $\mathrm{LD}_{50}$ of $1,233.9 \mathrm{mg} / \mathrm{kg}$ was determined (Oliveira et al., 2009). None study reported this assay on the target species of this review.

The lethality caused by a plant can be efficiently, quickly, and inexpensively tested in microcrustaceans of the species Artemia salina (Meyer, 1982; Pimenta et al., 2003). This method is safe and presents high specificity to detect bioactive compounds using small amounts of plant extracts (Lhullier et al., 2006; Koutsaftis and Aoyama, 2007). Although there are no studies demonstrating a direct relationship of Artemia salina test and a particular animal species, this bioassay has been considered to be effective in tracing substances toxic to zoological systems (Meyer, 1982).

Only four of the plants described in this review were evaluated for lethality using the A. salina test (Andrade et al., 2014; Ribeiro et al., 2014; Sprenger, 2015; Sprenger et al., 2016). Two plants, T. spinosa (Andrade et al., 2014) and Jatropha mollisima (Ribeiro et al., 2014), were identified as toxic, while Aloe vera (Sprenger, 2015) and Artemisia annua (Sprenger et al., 2016) showed good safety margins for animal use with a $\mathrm{DL}_{50}$ of $>1,000 \mathrm{~g} / \mathrm{mL}$ (Meyer et al., 1982). This test has not been widely used despite the ease of implementation, possibility of partitioning the bioactive principles of the plants, and ability to avoid the direct use of animals (Meyer et al., 1982).

\section{EVALUATION OF THE IN VITRO EFFECT OF PLANTS}

A total of $44 \%$ of the studies discussed in this review were performed exclusively in vitro to evaluate the reduction of viable egg counts by hatchability, larval development (from L1 to L3 larval stage), and motility of adult worm tests (Table 2). 
Table 2. List of plants with anthelmintic potential in goats and sheep tested exclusively in vitro and maximum activity obtained in the studies, from 2000 to 2018

\begin{tabular}{|c|c|c|c|c|}
\hline Plant & $\begin{array}{l}\text { Part of plant } \\
\text { used }\end{array}$ & Tests used & $\begin{array}{l}\text { Maximum } \\
\text { activity (\%) }\end{array}$ & Author \\
\hline Aster lanceolatus & Flowers & Hatchability & 91 & $\begin{array}{l}\text { Krychak-Furtado et } \\
\text { al., } 2011\end{array}$ \\
\hline \multirow{4}{*}{ Operculina halmiltonii } & \multirow{4}{*}{ Tubercle } & \multirow{2}{*}{ Hatchability } & 70.4 & Araújo et al., 2011 \\
\hline & & & 78.69 & Gomes et al., 2010 \\
\hline & & \multirow{2}{*}{ Larval development } & 66.8 & Araújo et al., 2011 \\
\hline & & & 33.34 & Gomes et al., 2010 \\
\hline \multirow{4}{*}{ Mormodica charantia } & \multirow{4}{*}{ Leaves } & \multirow{2}{*}{ Hatchability } & 35.47 & Gomes et al., 2010 \\
\hline & & & 44.9 & Cordeiro et al., 2010 \\
\hline & & \multirow{2}{*}{ Larval development } & 80.02 & Gomes et al., 2010 \\
\hline & & & 86.71 & Cordeiro et al., 2010 \\
\hline \multirow{2}{*}{ Azadirachta indica } & \multirow{2}{*}{ Seeds } & Hatchability & 80 & \multirow{2}{*}{ Salas et al., 2013} \\
\hline & & Larval development & 100 & \\
\hline \multirow{3}{*}{ Melia azedarach } & Leaves & Hatchability & 100 & \multirow{3}{*}{ Salas et al., 2013} \\
\hline & \multirow{2}{*}{ Seeds } & $\begin{array}{l}\text { Larval development } \\
\text { Hatchability }\end{array}$ & $\begin{array}{l}91.64 \\
100\end{array}$ & \\
\hline & & Larval development & 93.48 & \\
\hline \multirow{2}{*}{ Artemisia aпnиа } & \multirow{2}{*}{ Leaves } & Hatchability & 93.22 & \multirow{2}{*}{ Sprenger et al., 2016} \\
\hline & & Larval development & 90.33 & \\
\hline \multirow{2}{*}{ Myracrodruon urundeuva } & \multirow{2}{*}{ Leaves and stem } & Hatchability & 97.73 & \multirow{2}{*}{ Oliveira et al., 2011} \\
\hline & & Larval development & 83.56 & \\
\hline \multirow[b]{2}{*}{ Nicotiana tabacum } & \multirow[b]{2}{*}{ Leaves } & Hatchability & 99 & \multirow[b]{2}{*}{ Salas et al., 2013} \\
\hline & & Larval development & LT50 $=8 \pm 1$ min. $*$ & \\
\hline \multirow{2}{*}{ Aloe vera } & \multirow{2}{*}{ Pulp } & Hatchability & 94.35 & \multirow{2}{*}{ Sprenger, 2015} \\
\hline & & Larval development & 76.03 & \\
\hline \multirow{2}{*}{ Annona muricata } & Leaves & Hatchability & 84.91 & Ferreiraet al 2013 \\
\hline & & Larval development & 89.08 & \\
\hline Spigelia anthelmia & Aerial Part & $\begin{array}{l}\text { Hatchability } \\
\text { Larval development }\end{array}$ & $\begin{array}{l}100 \\
84.4\end{array}$ & Assis et al., 2003 \\
\hline Faoonvrum esculentum & Seeds & Hatchability & 19.66 & Gonçalves et al., \\
\hline & & Larval development & 17.66 & 2016 \\
\hline Agave sisalana & Leaves & $\begin{array}{l}\text { Hatchability } \\
\text { Larval development }\end{array}$ & $\begin{array}{l}100 \\
100\end{array}$ & Silveira et al., 2012 \\
\hline Carang auianensis & Seeds & Hatchability & 100 & Fariac et 12010 \\
\hline carapa gatanensts & & Larval development & 98.3 & \\
\hline Musa sp. & Residues & I arval develonment & 96 & Oliveira et al., 2010 \\
\hline & Fruit & Larval deveropment & 20.44 & Silva et al., 2013 \\
\hline Allium sativum & Garlic & Larval development & 99.34 & Almeida et al., 2004 \\
\hline Anacardium humile & Leaves & Larval development & 99.6 & Nery et al., 2010 \\
\hline Cecropia hololeuca & Leaves & Larval development & 8.10 & Silva et al., 2013 \\
\hline Abarema cochliacarpos & Stem & Larval development & 100 & Tenório et al., 2015a \\
\hline Eugenia uniflora & Leaves & Larval development & 14,87 & Tenório et al., 2015b \\
\hline
\end{tabular}


*Lethal Time $50=$ Time required for death of $50 \%$ of the population evaluated, in minutes, with extract concentration of 500-1000 ppm.

In vitro tests enable detection of anthelmintic properties in plant extracts, consisting of a preliminary step to characterize the possible active compounds present in plants with the potential to control parasitosis (Costa et al., 2002).

Extracts of Aldina sp., Phyllanthus attenuates, and Mabea nitida, Croton glandulosum, Tabernaemontana angulata, Caryocar microcarpum, Callaphyllum brasiliense, Guatteria riparia, and Trichilia sp. showed effects against Haemonchus sp. eggs at 100 $\mu \mathrm{g} / \mathrm{mL}$. However, these extracts did not inhibit larval development, even at a concentration of $200 \mu \mathrm{g} / \mathrm{mL}$ (Cunha et al., 2014).

Eugenia uniflora, Mentha piperita, Myrcianthes pungens, and Peltophorum dubium were tested at concentrations of $200,100,20$, and $2 \mathrm{mg} / \mathrm{mL}$ on ovine gastrointestinal nematode larvae. Only E. uniflora, at a concentration of 200 $\mathrm{mg} / \mathrm{mL}$, significantly reduced the number of total larvae, particularly against Haemonchus sp. and Tricostrongylus sp. (Hassum et al., 2013).

\section{EVALUATION OF THE IN VIVO EFFICACY OF PLANTS}

In spite of the trials in vivo provided more accurate information regarding the effectiveness of treatment in the host organism than in vitro tests, only $36 \%$ of the studies reviewed here carried out such trials (Table 3 ).

Allium sativum administered in natura (Holsbach et al., 2013) or in juice form (Santos et al., 2011) did not show action for RFEC. Leaves of S. terebinthifolius, $T$. avellanedae bark, and seed of Jatropha curcas was not effective for RFEC (Wolupeck et al., 2012). Likewise, Mimosa tenuiflora leaves administered for 3 days did not significantly reduce infective larvae of Haemonchus sp. (Oliveira et al., 2013). 
Table 3. List of plants with anthelmintic potential in goats and sheep tested exclusively in vivo and maximum effectiveness obtained in the studies, from 2000 to 2018

\begin{tabular}{|c|c|c|c|c|c|}
\hline Plant & $\begin{array}{l}\text { Part of } \\
\text { plant used }\end{array}$ & $\begin{array}{l}\text { Maximum } \\
\text { effectiveness } \\
(\%)\end{array}$ & $\begin{array}{l}\text { Animal } \\
\text { species used }\end{array}$ & $\begin{array}{l}\text { Number of } \\
\text { animals }\end{array}$ & Author \\
\hline \multirow{4}{*}{$\begin{array}{l}\text { Operculina } \\
\text { halmiltonii }\end{array}$} & \multirow{3}{*}{ Tubercle } & 80.7 & Goats & 240 & $\begin{array}{l}\text { Rodrigues et al., } \\
2007\end{array}$ \\
\hline & & 90 & Goats & 40 & $\begin{array}{l}\text { Brito-Júnior et al., } \\
2011\end{array}$ \\
\hline & & 72.32 & Goats & 40 & $\begin{array}{l}\text { Almeida et } 1 . \text {, } \\
2007\end{array}$ \\
\hline & Root & 84 & Goats & 30 & Silva et al., 2010 \\
\hline \multirow{3}{*}{$\begin{array}{l}\text { Mormodica } \\
\text { charantia }\end{array}$} & \multirow{3}{*}{ Leaves } & 40 & Goats & 40 & $\begin{array}{l}\text { Brito-Júnior et al., } \\
2011\end{array}$ \\
\hline & & 79.5 & Sheep & 24 & Coêlho et al, 2017 \\
\hline & & 63.06 & Goats & 40 & $\begin{array}{l}\text { Almeida et al., } \\
2007\end{array}$ \\
\hline \multirow{2}{*}{ Musa sp. } & \multirow{2}{*}{ Leaves } & 94.04 & Sheep & 24 & $\begin{array}{l}\text { Gregory et al., } \\
2015\end{array}$ \\
\hline & & 81 & Sheep & 26 & Parra et al., 2014 \\
\hline \multirow{2}{*}{$\begin{array}{l}\text { Azadirachta } \\
\text { indica }\end{array}$} & \multirow{2}{*}{ Seeds } & 29 & Sheep & 32 & $\begin{array}{l}\text { Soares Filho et al., } \\
2015\end{array}$ \\
\hline & & 37 & Sheep & 24 & $\begin{array}{l}\text { Igarashi et al., } \\
2013\end{array}$ \\
\hline Agave sisalana & Residues & 50.3 & Goats & 30 & Botura et al.,2011 \\
\hline Cratylia mollis & Leaves & 61.1 & Goats & 36 & $\begin{array}{l}\text { Mendonça Lima et } \\
\text { al., } 2016\end{array}$ \\
\hline Tagetes minuta & Aerial Parts & 51.5 & Sheep & 24 & Coêlho et al., 2017 \\
\hline Carica papaya & Seeds & 70 & Sheep & 45 & Pereira et al., 2013 \\
\hline $\begin{array}{l}\text { Lepidium } \\
\text { didymum }\end{array}$ & Aerial Parts & 63.7 & Sheep & 24 & Coêlho et al., 2017 \\
\hline Curcubita pepol & Seeds & 87.31 & Goats & 40 & $\begin{array}{l}\text { Almeida et al., } \\
2007\end{array}$ \\
\hline $\begin{array}{l}\text { Typha } \\
\text { domingensis }\end{array}$ & Rhizome & 48 & Goats & 30 & Silva et al., 2010 \\
\hline Melia azedarach & Fruit & 33.21 & Sheep & 24 & Falbo et al., 2008 \\
\hline
\end{tabular}

IN VITRO VERSUS IN VIVO EFFECT OF PLANTS WITH ANTHELMINTIC POTENTIAL

Only $20 \%$ of the reviewed studies performed the joint evaluation (in vitro and in vivo), establishing a parallel of the results obtained with the two methodologies. Most studies (90\%) did not replicate in vivo the promising results found in vitro. It is noteworthy that $80 \%$ of the studies were carried out in sheep and only $20 \%$ in goats (Table 4). 
Table 4. Maximum effectiveness of plants with anthelmintic potential in goats and sheep evaluated in vitro and in vivo assays, from 2000 to 2018

\begin{tabular}{|c|c|c|c|c|c|c|}
\hline Plant & $\begin{array}{l}\text { Part of } \\
\text { plant } \\
\text { used }\end{array}$ & $\begin{array}{l}\text { Maximum } \\
\text { effectiveness } \\
(\%) \\
\text { in vitro } \\
\end{array}$ & $\begin{array}{l}\text { Maximum } \\
\text { effectiveness } \\
(\%) \\
\text { in vivo } \\
\end{array}$ & $\begin{array}{l}\text { Animal } \\
\text { species } \\
\text { used }\end{array}$ & $\begin{array}{l}\text { Number } \\
\text { of } \\
\text { animals }\end{array}$ & Author \\
\hline $\begin{array}{l}\text { Zanthoxylum } \\
\text { rhoifolium }\end{array}$ & Leaves & & 92 & $\begin{array}{l}\text { Goats/ } \\
\text { Sheep* }\end{array}$ & 20 & $\begin{array}{lll}\text { Peneluc } & \text { e } & \text { al., } \\
2009 & & \end{array}$ \\
\hline $\begin{array}{l}\text { Agave } \\
\text { sisalana }\end{array}$ & $\begin{array}{l}\text { Liquid } \\
\text { Residue }\end{array}$ & $>95$ & 40 & Goats & 24 & $\begin{array}{l}\text { Domingues et } \\
\text { al., } 2010\end{array}$ \\
\hline $\begin{array}{l}\text { Tarenaya } \\
\text { spinosa }\end{array}$ & Root & 81.53 & 41 & Sheep & 20 & $\begin{array}{l}\text { Andrade et al., } \\
2014\end{array}$ \\
\hline $\begin{array}{l}\text { Jatropha } \\
\text { mollisima }\end{array}$ & Stem & 70.77 & 47.1 & Sheep & 20 & $\begin{array}{l}\text { Ribeiro et al., } \\
2014\end{array}$ \\
\hline $\begin{array}{l}\text { Cocos } \\
\text { nucifera }\end{array}$ & Fiber & 10 & 18.69 & Sheep & 18 & $\begin{array}{l}\text { Oiveira et al., } \\
2009\end{array}$ \\
\hline $\begin{array}{l}\text { Mangifera } \\
\text { indica }\end{array}$ & Fruit & 100 & 53 & Sheep & 24 & Nery et al., 2012 \\
\hline $\begin{array}{l}\text { Caryocar } \\
\text { brasiliensis }\end{array}$ & Bark & 98.7 & 33 & Sheep & 36 & $\begin{array}{l}\text { Nogueira et al., } \\
2012\end{array}$ \\
\hline $\begin{array}{l}\text { Piptadenia } \\
\text { viridiflora }\end{array}$ & Leaves & 90 & 47.2 & Sheep & 24 & $\begin{array}{l}\text { Morais Costa et } \\
\text { al., } 2016\end{array}$ \\
\hline $\begin{array}{l}\text { Ananas } \\
\text { comosus }\end{array}$ & Bark & 90 & 22 & Sheep & 36 & $\begin{array}{l}\text { Domingues et } \\
\text { al., } 2013\end{array}$ \\
\hline $\begin{array}{l}\text { Artemisia } \\
\text { апnиа }\end{array}$ & Leaves & 99 & 19 & Sheep & 24 & Cala et al., 2014 \\
\hline
\end{tabular}

*In vitro assay: goats; In vivo assay: sheep

\section{FINAL CONSIDERATIONS}

The use of plants with anthelmintic potential, regardless of the preparation process, has revealed the action of active substances with varying levels of efficacy in small ruminants.

Operculina hamiltonii and Musa sp. are effective for the reduction of endoparasitary infestation in small ruminants, and the metabolites polyphenols, including condensed tannins, are responsible for this activity. Mormodica charantia also presents a high activity to reduce endoparasitoses, and triterpenos glycosides and mormodicinas are the active components. Zanthoxylum rhoifolium and Curcubita pepol have high anthelmintic activity; however, there is still no description of its active components. Other plant species, cited in this review, have antiparasitic activity; yet, this effect has been determined, so far, only in vitro assays. Considering that the metabolomic composition of plants can vary according to the environmental conditions, different edaphoclimatic conditions, use of plants at different vegetative stages or even use of different parts of the plant may be pointed out as causes of variation of results obtained in different studies carried out with the same plant.

The difficulty of in vivo replication of results achieved in vitro may be due to intrinsic factors to the animals; laboratory tests use eggs and/or larvae isolated, without the interference of the organic matter, unlike what occurs in the animals; most in vitro larval trials are not done with infective larvae within the parasitic cycle of worms, which may 
lead to divergences with the in vivo assays.

The accomplishment of preliminary tests of toxicity and lethality of the plants and their derivatives are needed to ensure the welfare of animals undergoing experimentation.

Notwithstanding some species of plants with taniferous contents present high anthelmintic activity, studies on the substances responsible for this action are lacking. The identification and isolation of these active molecules will aid in the promotion of medicinal plants and, possibly, in the investment for the production of natural anthelmintic substances.

\section{ACKNOWLEDGEMENTS}

The authors would like to thank the FAPESB (Foundation for protection of research in the state of Bahia) for the financial support.

\section{REFERENCES}

ALMEIDA, M.A.O., SIMAS, M.M.S., BOTURA, M.B., BITIENCOURT, T.C.B.S.C., SILVA, A., BATATINHA, M.J.M. Avaliação in vitro dos efeitos do extrato alcoólico e do suco de alho (Allium sativum L.) sobre nematódeos gastrintestinais de caprinos. Ciência Veterinária nos Trópicos, v. 1, n.1, p.36-43, 2004.

ALMEIDA, W.V.F., SILVA, M.L.C.R., FARIAS, E.B., ATHAYDE, A.C.R., SILVA, W.W. Avaliação de plantas medicinais em caprinos da região do semi-árido paraibano naturalmente infectados por nematóides gastrintestinais. Revista Caatinga, v.20, n.3, p.1-7, 2007.
ANDRADE, F.D., RIBEIRO, A.R.C., MEDEIROS, M.C., FONSECA, A.C.R.A., FERREIRA, A.F., RODRIGUES, O.G., SILVA, W.W. Ação anti-helmíntica do extrato hidroalcoólico da raiz da Tarenaya spinosa (Jacq.) Raf. no controle de Haemonchus contortus em ovinos. Pesquisa Veterinária Brasileira, v.34, n.10, p.942-946, 2014.

ARAÚJO, M.M., VILELA, V.L.R., SILVA, W.A., SOUSA, R.V.R., FEITOSA, T.F., ATHAYDE, A.C.R. Eficácia anti-helmíntica in vitro do extrato etanólico de Operculina hamiltonii (G. Don) D.F. Austin \& Staples (1983) - batata de purga. Ars Veterinária, v.27, n.3, p.192-196, 2011.

ARRARES, A.I.O.M., LONGHIN, S.R. Otimização de ensaio de toxicidade utilizando o bioindicador Allium cepa como organismo teste. Enciclopédia

Biosfera, v.8, n.14, p.1959-1952, 2012. ASSIS, L.M., BEVILAQUA, C.M.L., MORAIS, S.M., VIEIRA, L.S., COSTA, C.T.C., SOUZA, J.A.L. Ovicidal and larvicidal activity in vitro of Spigelia anthelmia Linn. Extracts on Haemonchus contortus. Veterinary Parasitology, v.117, p.43-49, 2003.

ATAIIDE, H.S. DE; CANSI, E.R. Ocorrência das doenças parasitárias em ovinos e caprinos no Distrito Federal, Brasil, durante 2003 a 2009. Arquivos do Instituto Biológico, v.80, n.3, p.342-345, 2013.

BELOIN, N.; GBEASSOR, M.; AKPAGANA, K.; HUDSON, J.; SOUSSA, K.; KOUMAGLO, K.; ARNASON, J. T. Ethonomedicinal uses of Mormodica charantia

(Curcubitaceae) in Togo and relation to its phytochemistry and biological 
activity. Journal of

Ethnopharmacology, v.29, p.49-55,

2005.

BOTURA, M.B., SILVA, G.D., LIMA, H.G., OLIVEIRA, J.V.A., SOUZA, T.S., SANTOS, J.D.G., BRANCO, A., MOREIRA, E.L.T., ALMEIDA, M.A.O., BATATINHA, M.J.M. In vivo anthelmintic activity of an aqueous extract from sisal waste (Agave sisalana Perr.) against gastrointestinal nematodes in goats. Veterinary Parasitology, v.177, p.104-111, 2011.

BRAGA, R. Plantas do Nordeste, especialmente do Ceará. Imprensa Oficial, Fortaleza. 1960.

BRITO-JUNIOR, L., SILVA, M.L.C.R., LIMA, F.H., ATHAYDE, A.C.R., SILVA, W.W., RODRIGUES, O.G. Estudo comparativo da ação antihelmíntica da batata de purga (Operculina hamiltonii) e do melão de São Caetano (Mormodica charantia) em caprinos (Capra hircus) naturalmente infectados. Ciência e Agrotecnologia, v.35, n.4, p.797-802, 2011.

CALA, A.C., FERREIRA, J.F.S., CHAGAS, A.C.S., GONZALEZ, J.M., RODRIGUES, R.A.F., FOGLIO, M.A., OLIVEIRA, M.C.S., SOUSA, I.M.O., MAGALHÃES, P.M. JÚNIOR, W.B. Anthelmintic activity of Artemisia annua L. extracts in vitro and the effect of anaqueous extract and artemisinin in sheep naturally infected with gastrointestinal nematodes.

Parasitology Research, v.113, n.6, p.2345-2353, 2014.

COÊLHO, M.D.G., XAVIER, T.B., COSTA J.F., MACIEL, L.T.R., BOZO, L.S.O., COÊLHO, F.A.S., AKISUE, G. Avaliação do uso de extratos vegetais para controle da hemoncose em ovinos naturalmente infectados. Revista
Ambiente e Água, v.12, n.2, p.331-339, 2017.

CORDEIRO, L.N., ATHAYDE, A.C.R., VILELA, V.L.R., COSTA, J.G.M., SILVA, W.A., ARAUJO, M.M., RODRIGUES, O.G. Efeito in vitro do extrato etanólico das folhas do melão-de-São-Caetano (Momordica charantia L.) sobre ovos e larvas de nematóides gastrintestinais de caprinos.

Revista Brasileira de Plantas

Medicinais, v.12, n.4, p.421-426, 2010. CORREA A., M.D., GALDAMES, C., STAPF, M.S. Catálogo de las plantas vasculares de Panamá. Smithsonian Tropical Research Institute, Panamá. 2004.

COSTA, C.T.C., MORAIS, S.M., BEVILAQUA, C.M.L., SOUZA, M.M.C., LEITE, F.K.A. Efeito ovicida de extratos de sementes de Mangifera indica L. sobre Haemonchus contortus. Revista Brasileira de Parasitologia Veterinária, v.11, n.2, p.57-60, 2002.

COSTA, P.T., COSTA, R.T., MENDONÇA, G., VAZ, R.Z. Eficácia anti-helmíntica comparativa do nitroxinil, levamisol, closantel, moxidectina e fenbendazole no controle parasitário em ovinos. Boletim de Indústria Animal, v.74, n.1, p.72-78, 2017.

CUNHA, L.C., MELO, D.F.A., PEREIRA, M.E., MELO, D.S., PARENTE, L.L., SILVA, M.A.C., CONCEIÇÃO, E.C., GONZAGA, L.Q.S. Avaliação da toxicidade aguda do extrato aquoso de Apeiba tibourbou Aubl (Tiliaceae) em camundongos e ratos. Revista de Ciências Farmacêuticas Básica e Aplicada, v.34, n.3, p.357-362, 2013.

CUNHA, M.P.V., ALVES NETO, A.F., SUFFREDINI, I.B., ABEL, L.J.C. 
Avaliação da atividade anti-helmíntica de extratos brutos de plantas da Floresta Amazônica e Mata Atlântica brasileira sobre Haemonchus contortus. Arquivo Brasileiro de Medicina Veterinária e Zootecnia, v.66, n.2, p.374-380, 2014.

DAVIDSE, G., SÁNCHEZ, M.S., KNAPP, S., CABRERA, F.C.

Rubiaceae a Verbenaceae. 4 (2). In. Davidse, G., Sánchez, M.S., Knapp, S.D., Cabrera, F.C. Flora.

Mesoamericana. Missouri Botanical Garden, St. Louis. 2012.

DOMINGUES, L.F., BOTURA, M.B., CRUZ, A.C.F.G., YUKI, C.C., SILVA, G.D., COSTA, M.S., MURPHY, G., MOREIRA, E.L.T., MENESES, I.D.S., ALMEIDA, M.G.A.R., BRANCO, A., ALMEIDA, M.A.O., BATATINHA, M.J.M. Evaluation of anthelmintic activity of liquid waste of Agave sisalana (sisal) in goats. Revista Brasileira de Parasitolologia Veterinária, v.19, n.4, p.270-272, 2010.

DOMINGUES, L.F., GIGLIOTI, R., FEITOSA, K.A., FANTATTO, R.R., RABELO, M.D., M.C.S., BECHARA, G.H., OLIVEIRA, G.P., JUNIOR, W.B., CHAGAS, A.C.S. In vitro and in vivo evaluation of the activity of pineapple (Ananas comosus) on Haemonchus contortus in Santa Inês sheep. Veterinary Parasitology, v.197, p.263-270, 2013.

DUX, J. P., STALZER, R.F. Managing Safety in the Chemical Laboratory. Van Nostrand Reinhold, New York. 1988.

EGUALE, T., TILAHUN, G., DEBELLA, A., FELEKE, A., MAKONNEN, E. In vitro and in vivo anthelmintic activity of crude extratos of Coriandrum sativum against Haemonchus contorturs. Journal of Ethnopharmacology, v.110, n.3, p.428-433, 2007.

EL SHAFIE, H. A. F.; BASEDOW, T. The efficacy of different neem preparations for the control of insects damaging potatoes and eggplants in the Sudan. Crop Protection, v.22, n.8, p.1015-1021, 2003.

FALBO, M.K., SANDINI, I.E., ISHIY, H.M., FÁVARO, J.L., SANTOS, C.E., BASTOS, S., RODIGHERI, D., GUZZO, D. Atividade anti-helmíntica do fruto da Melia azedarach em cordeiros naturalmente infectados com nematódeos gastrintestinais. Semina: Ciências Agrárias, v.29, n.4, p.881886, 2008.

FANG, Q.M., ZHANG, H., CAO, Y., WANG, C. Anti-inflammatory and free radical scavenging activities of ethanol extracts of three seeds used as "Bolengguazi". Journal of Ethnopharmacology, v.114, p.61-65, 2007.

FARIAS, M.P.O., TEIXEIRA, W.C., WANDERLEY, A.G., ALVES, L.C., FAUSTINO, M.A.G. Avaliação in vitro dos efeitos do óleo da semente de Carapa guianensis Aubl. Sobre larvas de nematóides gastrintestinais de caprinos e ovinos. Revista Brasileira de Plantas Medicinais, v.12, n.2, p.220-226, 2010.

FERREIRA, L.E., CASTRO, P.M.N., CHAGAS, A.C.S., FRANÇA, S.C., BELEBONI, R.O. In vitro anthelmintic activity of aqueous leaf extract of Annona muricata L. (Annonaceae) against Haemonchus contortus from sheep. Experimental Parasitology, v.134, p.327-332, 2013. 
FISKESJO, G. The Allium test as a standard in environmental monitoring. Hereditas, v.102, p.99-112,1985.

FMI - FUTURE MARKETING

INSIGHT. Animal Healthcare Market Rising Trend of Pet Adoption to Drive Market Growth. Global Industry Analysis 2012 - 2016 and Opportunity Assessment 2017 - 2027. 2017.

FORBES, V.E.; FORBES, T.L.

Ecotoxicology in theory and pratice. Chapman and Hall, London. 1994.

FRANCIS, G., KEREM, Z., MAKKAR, H.P.S., BECKER, K. The biological action of saponins in animal systems: a review. British Journal of Nutrition, v.88, p.587-605, 2002.

FRANCO, A.L., NOGUEIRA, M.N.M., SOUSA, N.G.K., FROTA, M.F., FERNANDES, C.M.S.F., SERRA, M.C. Pesquisas em animais: uma reflexão bioética. Acta Bioethica, v.20, n.2, p.247-253, 2014

FURTADO, F.N., SILVA, V.A.R., PEREIRA, J.R., AKISUE, G.A., COÊLHO, F.A.S., COÊLHO, M.D.G. Avaliação in vitro do potencial acaricida do óleo essencial de Tagetes minuta frente a Riphicephalus (Boophilus) microplus (Canestrini, 1887). Revista Biociências, v.19, n.1, p.104-110, 2013.

GOMES, R.V.R.S., ARAÚJO, M.M., GOMES, E.N., VILELA, V.L.R., ATHAYDE, A.C.R. Ação antiparasitária in vitro dos extratos etanólicos de Operculina hamiltonii (batata de purga) e Momordica charantia (melão de São Caetano) sobre ovos e larvas de nematóides gastrintestinais de caprinos do semi- árido paraibano. Acta Veterinária

Brasílica, v.4, n.2, p.92-99, 2010.

GONÇALVES, F.M.F., DEBIAGE, R.R., YOSHIHARA, E., SILVA, R.M.G., PORTO, P.P., GOMES, A.C., PEIXOTO, E.C.T.M. Anthelmintic and antioxidante potential of Fagopyrum esculentum Moench in vitro. African Journal of Agricultural Research, v.11, n.44, p.4454-4460, 2016.

GREGORY, L., YOSHIHARA, E., RIBEIRO, B.L.M., SILVA, L.K.F., MARQUES, E.C., MEIRA JÚNIOR, E.B.S., ROSSI, R.S., SAMPAIO, P.H., LOUVANDINI, H., HASEGAWA, M.Y. Dried, ground banana plant leaves (Musa spp.) for the control of Haemonchus contortus and Trichostrongylus colubriformis infections in sheep. Parasitolology Research, v.114, p. 4545-4551, 2015.

HAMMEL, B. E. Convolvulaceae. En: Manual de Plantas de Costa Rica. HAMMEL, B.E., GRAYUM, M.H., HERRERA, C., ZAMORA, N. Monographs in Systematic Botany from the Missouri Botanical Garden, v.119, p.72-126, 2010.

HASAN, F.; ANSARI, M.S. Toxic effects of neem-based insecticides on Pieris brassicae (Linn.). Crop Prot, v. 30, n.4, p. 502-507, 2011.

HASSUM, I.C., VENTURI, C.R., GOSMANN, G., DEIRO, A.M.G. Ação dos extratos de quatro plantas sobre larvas infectantes de nematódeos gastrintestinais de ovinos. Revista Cubana de Plantas Medicinales, v.18, n.2, p. 278-287, 2013.

HAYES, W. A., DIPASQUALE, L.C. Acute toxicity and eye irritance. In: HAYES, A.W. Principles and Methods 
of Toxicology. Taylor \& Francis, Philadelphia, 2001.

HOLLENBACH, C.B.; BING, R. S. ; STEDILE, R. ; MELLO, F. P. S. ; SCHUCH, T. L. ; RODRIGUES, M. R. A. ; Mello, F.B. ; MELLO, J. R.

B. Reproductive toxicity assessment of Origanum vulgare essencial oil on male wistar rats. Acta Scientiae

Veterinariae, v.43, p. 1295, 2015.

HOLSBACK, L., PORTO, P.P., MÁRQUEZ, E.S., PORTO, P.E. Fitobioterapia no controle de nematódeos gastrointestinais de ovinos. Semina: Ciências Agrárias, v. 34, n. 2, p. 38413850, 2013.

HOSTE, H., JACKSON, F., ATHANASIADOU, S., THAMSBORG, S.M., HOSKIN, S.O. The effects of tannin-rich plants on parasitic nematodes in ruminants.

Trends Parasitology. v.22, p.256-261, 2006.

IGARASHI, M., CARVALHO, D.M.G., BUCCI, F.C., MIRANDA, Y., RODRIGUES, Z.M., ALMEIDA, M.C.F., PIONA, M.N.M. Efeito do nem (Azadirachta indica) no controle de nematódeos gastrintestinais em ovinos suplementados a pasto no período seco. Semina: Ciências Agrárias, v.34, n.1, p.201-310, 2013.

KARUPPIAH, P., MUSTAFFA, M. Antibacterial and antioxidant activities of Musa sp. leaf extracts against multidrug resistant clinical pathogens causing nosocomial infection. Asian Pacific Journal of Tropical Biomedicine, v.3, n.9, p.737-742, 2013.

KOUTSAFTIS, A., AOYAMA, I. Toxicity of four antifouling biocides and their mixtures on the brine shrimp
Artemia salina. Science of the Total

Environment, v.387, p.166-174, 2007.

KRYCHAK-FURTADO, S., SILVA, A.L.P., MIGUEL, O.G., DIAS, J.F.G., MIGUEL, M.D., COSTA, S.S., NEGRELLE, R.R.B. Effectiveness of Asteracceae extracts on Trichostrongylidae eggs in sheep. Revista Brasileira de Parasitologia Veterinária, v.20, n.3, p.215-218, 2011.

LANS, C., HARPER, T., GEORGES, K., BRIDGEWATER, E. Medicinal plants used for dogs in Trinidad and Tobago. Preventive Veterinary Medicine, v.45, p.201-220, 2000.

LHULLIER, C., HORTA, P.A., FALKENBERG, M. Avaliação de extratos de macroalgas bênticas do litoral catarinense utilizando o teste de letalidade para Artemia salina. Revista Brasileira de Farmacognosia, v.16, p.158-163, 2006.

LIMA, C.M.B.L., FREITAS, F.I.S., MORAIS, L.C.S.L., CAVALCANTI, M.G.S., SILVA, L.F., PADILHA, R.J.R., BARBOSA, C.G.S., SANTOS, F.A.B., ALVES, L.C., DINIZ, M.F.F.M. Ultrastructural study on the morphological changes to male worms of Schistosoma mansoniafter in vitro exposure to allicin. Revista da Sociedade Brasileira de Medicina Tropical, v.44, n.3, p.327-330, 2011.

LOLAS, F. Bioethics and animal research. A personal perspective and a note on the contribution of Fritz Jahr.

Biological Research, v.41, n.1, p.119123, 2008.

MACIEL, M.V., MORAIS, S.M., BEVILAQUA, C.M.L., CAMURÇA VASCONCELOS, A.L.F., COSTA, C.T.C., CASTRO, C.M.S. Ovicidal and 
larvicidal activity of Melia azedarach extracts on Haemonchus contortus.

Veterinary Parasitology, v.140, p.98104, 2006.

MARIE-MAGDELEINE, C., HOSTE, H., MAHIEU, M., VARO, H., ARCHIMEDE, $\mathrm{H}$. In vitro effects of Cucurbita moschataseed extracts on Haemonchuscontortus. Veterinary

Parasitology, v.161, p.99-105, 2009.

MELO, V.F.P., PINHEIRO, R.S.B., HOMEM JUNIOR, A.C., AMÉRICO, J.H.P., SANTOS, V.C.,

ROSESTOLATO, L.L.R. Manejo de anti-helmínticos no controle de infecções gastrintestinais em cabras.

Revista Brasileira de Saúde e Produção Animal, v.16, n.4, p.916924, 2015.

MENDONÇA-LIMA, F.W., SANTOS, R.B., SANTOS, L.C., ZACHARIAS, F., DAVID, J.M., DAVID, J.P., LÓPEZ, J.A. Anthelmintic activity of Cratylia mollis leaves against gastrointestinal nematodes in goats.

Revista Brasileira de Saúde e Produção Animal, v.17, n.4, p.753762, 2016.

MEYER, B. N., FERRIGNI, N. R., PUTNAN, J. E., JACOBSEN, L. B., NICHOLS, D. E., MCL. AUGHLIN, J. Brine shrimp: A convenient general bioassay for active plant constituents. Journal of Medicinal Plants

Research, v.45, n.1, p. 31-34, 1982.

MOLENTO, M.B., FORTES, F.S., PONDELEK, D.A.S., BORGES, F.A., CHAGAS, A.C.S., TORRES-ACOSTA, J.F.J., GELDHOF, P. Challenges of nematode control in ruminants: Focus on Latin America. Veterinary

Parasitology, v.180, p.126-132, 2011.
MOLENTO, M.B., VERISSIMO, C.J., AMARANTE, A.T., VAN WYK, J.A., CHAGAS, A.C.S., DE ARAÚJO, J.V., BORGES, F.A. Alternativas para controle de nematoides gastrintestinais de pequenos ruminantes. Arquivos do Instituto Biológico, v.80, n.2, p.253263, 2013.

MORAIS-COSTA, F., BASTOS, G.A., SOARES, A.C.M., COSTA, E.G.L., VASCONCELOS, V.O., OLIVEIRA, N.J.F., BRAGA, F.C., DUARTE, E.R., LIMA, W.S. In vitro and in vivo action of Piptadenia viridiflora (Kunth) Benth against Haemonchus contortus in sheep. Veterinary Parasitolology, v.223, p.43-49, 2016.

NERY, P.S., NOGUEIRA, F.A., MARTINS, E.R., DUARTE, E.R. Effects of Anacardium humile leaf extracts on the development of gastrointestinal nematode larvae of sheep. Veterinary Parasitolology, v.171, p.361-364, 2010.

Nery, P.S., Nogueira, F.A., Oliveira, N.J.F., Martins, E.R., Duarte, E.R. Efficacy of extracts of immature mango on ovine gastrointestinal nematodes.

Parasitology Research, v.111, n.6, p.2467-2461, 2012.

NEVES, B.P.; OLIVEIRA, I.P.; NOGUEIRA, J.C.M. Cultivar e utilização do nim indiano. Embrapa Arroz Feijão, Goiás (Circular Técnica, 62), 2003.

NOGUEIRA, F.A., FONSECA, L.D., SILVA, R.B., FERREIRA, A.V.P., NERY, P.S., GERASEEV, L.C., DUARTE, E.R. In vitro and in vivo efficacy of aqueous extract of Caryocar brasiliense Camb. to control gastrointestinal nematodes in sheep 
Parasitology Research, v.111, p. 325330, 2012.

OLIVEIRA, L.M.B., BEVILAQUA, C.M.L., COSTA, C.T.C., MACEDO, I.T.F., BARROS, R.S., RODRIGUES, A.C.M., CAMURÇA-

VASCONCELOS, A.L.F., MORAIS, S.M., LIMA, Y.C., VIEIRA, L.S., NAVARRO, A.M.C. Anthelmintic activity of Cocos nucifera $\mathrm{L}$. against sheep gastrointestinal nematodes. Veterinary Parasitolology, v.159, p.55-59, 2009.

OLIVEIRA, L.M.B., BEVILAQUA, C.M.L., MACEDO, I.T.F., MORAIS, S.M., MACHADO, L.K.A., CAMPELLO, C.A., MESQUITA, M.A. Effects of Myracrodruon urundeuva extracts on egg hatching and larval exsheathment of Haemonchus contortus. Parasitology Research, v.109, p.893-898, 2011.

OLIVEIRA, L.M.B., MACEDO, I.T.F., VIEIRA, L.S., CAMURÇAVASCONCELOS, A.L.F., TOMÉ, A.R., SAMPAIO, R.A., LOUVANDINI, H., BEVILAQUA, C.M.L. Effects of Mimosa tenuiflora on larval establishment of Haemonchus contortus in sheep. Veterinary

Parasitolology, v.196, p.341-346, 2013.

OLIVEIRA, L.N., DUARTE, E.R., NOGUEIRA, F.A., SILVA, R.B., FILHO, D.E.F., GERASEEV, L.C. Eficácia de resíduos da bananicultura sobre a inibição do desenvolvimento larval em Haemonchus spp. provenientes de ovinos. Ciência Rural, v.40, n.2, p.488-490, 2010.

OLIVEIRA, V.B., ZUCHETTO, M., OLIVEIRA, C.F., PAULA, C.S., DUARTE, A.F.S., MIGUEL, M.D., MIGUEL, O.G. Efeito de diferentes técnicas extrativas no rendimento, atividade antioxidante, doseamentos totais e no perfil por CLAE-DAD de Dicksonia sellowiana (presl.). Hook, Dicksoniaceae. Revista Brasileira de Plantas Medicinais, v.18, n.1, supl. I, p.230-239, 2016.

OSBOURN, A.E. Preformed antimicrobial compounds and plant defense against fungal attack. Plant Cell, v.8, n.10, p.1821-1831, 1996.

PARRA, C.L.C., OLIVO, C.J., FLORES, F.S., AGNOLIN, C.A., PIRES, C.C., BOLZAN, A.M.S. Alteração da carga de endoparasitas em ovinos submetidos a diferentes níveis de folha de bananeira na alimentação.

Revista Brasileira de Agroecologia, v.6, n.2, p.111-116, 2011.

PENELUC, T., DOMINGUES, L.F., ALMEIDA, G.N., AYRES, M.C.C., MOREIRA, E.L.T., CRUZ, A.C.F., BITTENCOURT, T.C.B.S.C., ALMEIDA, M.A.O., BATATINHA, M.J.M. Atividade anti-helmíntica do extrato aquoso das folhas de Zanthoxylum rhoifolium Lam.

(Rutaceae). Revista Brasileira

Parasitologia Veterinária, v.18, p.4348, 2009.

PEREIRA, J.S., PESSOA, H.F., BESSA, E.N., NASCIMENTO, J.O., COÊLHO, W.A.C., FONSECA, Z.A.A.S., AHID, S.M.M. Avaliação do extrato de semente de mamão formosa (Caricapapaya, Linnaeus) no controle de endoparasitas de ovinos no Rio Grande do Norte, Brasil. Acta Veterinaria Brasilica, v.7, n.1, p.4851, 2013.

PIMENTA, L.P.S.; PINTO, G.B.; TAKAHASHI, J.A.; SILVA, L.G.F.; BOAVENTURA, M.A.D. Biological 
screening of annonaceous brazilian medicinal plants using Artemia salina (Brine Shrimp Test). Phytomedicine, v.10, p.209-212, 2003.

RIBEIRO, A.R.C., ANDRADE, F.D., MEDEIROS, M.C., CAMBOIM, A.S., JÚNIOR, F.A.P., ATHAYDE, A.C.R., RODRIGUES, O.G., SILVA, W.W. Estudo da atividade anti-helmíntica do extrato etanólico de Jatropha molíssima (Pohl) Baill. (Euphorbiaceae) sob Haemonchus contortu sem ovinos no semiárido paraibano. Pesquisa Veterinária Brasileira, v.34, n.11, p.1051-1055, 2014.

RODRIGUES, A.B., ATHAYDE, A.C.R., RODRIGUES, O.G., SILVA, W.W., FARIA, E.B. Sensibilidade dos nematóides gastrintestinais de caprinos a anti-helmínticos na mesorregião do Sertão Paraibano. Pesquisa Veterinária Brasileira, v.27, n.4, p.162-166, 2007. SALAS, R.Z., AGUDE, C.G., CARDONA, L.N.M., TAMAYO, I.Y.U., ECHEVERRY, D.P., MARINS, P.A. Actividad antihelmintica in vitro de extractos oleosos de Azadirachta indica y extractos acuosos de Nicotiana tabacum sobre nematodos gastrointestinales de cabras. Revista de Medicina Veterinária, v.26, n.25-36, 2013.

SANTOS, D'A.J. 2006. Produção e consumo. In: ANDRADE, W. (org.). $\mathbf{O}$ sisal no Brasil. SINDIFIBRAS, Salvador. Apex, Brasília. SANTOS, F.C.C., VOGEL, F.S.F., MONTEIRO, S.G. Efeito do suco de alho (Allium sativum L.) sobre endoparasitas gastrintestinais de ovinos. Revista Brasileira de Agroecologia, v.6, n.3, p.176-181, 2011.

SANTOS, P.L., PRANDO, M.B., MORANDO, R., PEREIRA, G.V.N.,
KRONKA, A. Z. Utilização de extratos vegetais em proteção de plantas.

Enciclopédia Biosfera, v.9, n.17, p.2562-2576, 2013.

SAXENA, R.C. Naturally ocurrig pesticides and their potential. In: L. W. SHEMILT (ed.). Chemistry and World Food Supplies: The New Frontiers. Pergamon Press, Oxford. 1983

SEP. Hershberger Assay. OCSPP Guideline 890.1400. Standard Evaluation Procedure (SEP). Endocrine Disruptor Screening Program. 2011. 16p.

SHALDERS, E., FREITAS ZANINI, S.F., SOUSA, D.R., BARIONI, G., CLIPES, R.C., AVELAR, B.R., SUHET, J.M.M. Percentual de suplementação de fonte tanífera na ração concentrada de caprinos jovens sobre o desempenho e carga parasitária. Ciência Rural, v.44, n.6, p.1100-1105, 2014

SIDRA- IBGE. Sistema IBGE de recuperação automática. Instituto de Brasileiro de Geografia e Estatística.

Censo Agropecuário 2017 resultados preliminares.

https://sidra.ibge.gov.br/pesquisa/censoagropecuario/censo-agropecuario-2017 (acessed 27 july 2018), 2018.

SILVA, A.B., CÉSAR, V.S., SANTOS, A.C.G., GUERRA, R.M.S.N.C. Avaliação do efeito dos extratos de Cecropiahololeuca (embaúba) e Musa sp. variedade FHIA 18 (bananeira) sobre culturas de larvas de nematódeos gastrintestinais de caprinos.

Enciclopédia Biosfera, v.9, n.16, p.411-422, 2013. 
SILVA, C.F., ATHAYDE, A.C.R., SILVA, W.W., RODRIGUES, O.G., VILELA, V.L.R., MARINHO, P.V.T. Avaliação da eficácia de taboa (Typha domingensis Pers.) e batata-de-purga [Operculina hamiltonii (G. Don) D.F. Austin \& Staples] in natura sobre nematóides gastrintestinais de caprinos, naturalmente infectados, em clima semi-árido. Revista Brasileira de Plantas Medicinais, v.12, n.4, p.466471, 2010.

SILVA, S.L., NASCIMENTO, A.A., RIBEIRO, E.F.B., RIBEIRO, R.B., ALVES, C.M., SANTOS, A.M., BURMANN, A.P.R., MIRA NETO, R.A. Avaliação da toxicidade aguda pré-clínica do extrato metanólico das cascas do caule de Parahancornia amapa (Apocynaceae). Acta

Amazônica, v.46, n.1, p.73-80, 2016.

SILVEIRA, R.X., CHAGAS, A.M.C.S., BOTURA, M.B., BATATINHA, M.J.M., KATIKI, L.M., CARVALHO, C.O., BEVILAQUA, C.M.L., BRANCO, A., MACHADO, E.A.A., BORGES, S.L., ALMEIDA, M.A.O. Actionof sisal (Agave sisalana, Perrine) extract in the in vitro development of sheep and goat gastrointestinal nematodes. Experimental

Parasitology, v.131, p.162-168, 2012.

\section{SINDAN. Sindicato nacional da} indústria de produtos para saúde animal.

http://www.sindan.org.br/sd/base.aspx? controle $=8$ (accessed 15 june 2018), 2018.

SOARES FILHO, C.V., ROSA, P.R.B., COSTA, R.L.D., SPADA, J.C.P. Óleo de Neem (Azadirachta indica) nos parâmetros parasitológicos, hematológicos e bioquímicos de ovinos naturalmente infectados por nematoides gastrintestinais. Revista Brasileira de Saúde e Produção Animal, v.16, n.2, p.408-419, 2015.

SOUZA, J.D.F., GUIMARÃES, V.P., MAGALHÃES, K.A., BARBOSA, C.M.P., MARTINS, E.C., HOLANDA FILHO, Z.F., MENDES, M.E.P. Ativos Ovinos e Caprinos. CNA Brasil, 2016. SPRENGER, L.K. Atividade ovicida e larvicida do extrato etanólico de Aloe vera $\mathrm{L}$. sobre Haemonchus contortus. Revista Brasileira de Parasitologia Veterinária, v.22, n.3-4, p.152-156, 2015.

SPRENGER, L.K., MAUER, J.B.B., BAGGIO, S.F.Z., MAGALHÃES, P.M., MOLENTO, M.B. Atividade ovicida e larvicida do extrato hidroalcoólico de Artemisia annua sobre Haemonchus contortus. Archives of Veterinary Science, v.21, n.4, p.5765, 2016.

SPRENGER, L.K., RISOLIA, L.W., GABARDO, L.B., MOLENTO, M.B., SILVA, A.W.C., SOUSA, R.S. Doenças de ruminantes domésticos diagnosticadas no laboratório de patologia veterinária da Universidade Federal do Paraná: 1075 casos.

Archives of Veterinary Science, v.20, n.4, p.45-53, 2015.

STATISTA.The Statistics Portal. Global animal health market size from 2002 to 2016 (in billion U.S. dollars).

https://www.statista.com/statistics/8861 24/e-cigarette-t-vapor-market-globalsize/ (acessed 08 june 2018), 2018. TENÓRIO, R.F.L., AMARAL, R.L.G., NASCIMENTO, M.S., ALVES, L.C., FAUSTINO, M.A.G. Ação antihelmíntica in vitro do extrato etanólico da casca do caule de Abarema 
cochliacarpos (barbatimão) sobre larvas de nematoides gastrintestinais de caprinos e ovinos. Ciência Veterinária nos Trópicos, v.18, n.2, p.213-216, 2015a.

TENÓRIO, R.F.L., SILVA, G.R., MARINHO, G.L.O.C., ALVES, L.C., FAUSTINO, M.A.G. Avaliação in vitro do efeito larvicida do extrato aquoso das folhas de pitangueira (Eugenia uniflora L) contra nematóides gastrinstestinais de caprinos. Ciência Veterinária nos Trópicos, v.18, n.2, p.171-174, 2015 b.

TOKARNIA, C.H., BRITO, M.F., BARBOSA, J.D. Plantas tóxicas do Brasil para animais de produção. Helianthus, Rio de Janeiro. 2012.

VALADARES, M.C. Avaliação de toxicidade aguda: estratégias após a "Era do teste DL50". Revista

Eletrônica de Farmácia, v.3, n.2, p.9398, 2006.

WANG, Y., LI, X., SUN, H., YI, K., ZHENG, J., ZHANG, J., HAO, Z. Biotransformation os steroidal saponins in sisal (Agave sisalana Perrine) To tigogenin by a newly isolated strain from a karst area of Guilin, China.

Biotechnology \& Biotechnological Equipment, v.28, n.6, p.1024-1033, 2014.

WOLUPECK, H.L., MAIA, D., OLLHOFF, R.D., TEIXEIRA, V., PASSERINO, A.S., SOTOMAIOR, C.S. Aroeira (Schinus Terebinthifolius), ipê roxo (Tabebuia avellanedae) e pinhão manso (Jatropha curcas) no tratamento oral da verminose gastrintestinal de caprinos. Revista Acadêmica: Ciências Agrárias e Ambientais, v.10, n.2, p.197-204, 2012.
XYNOS, N., PAPAEFSTATHIOU, G., PSYCHIS, M., ARGYROPOULOU, A., ALIGIANNIS, N., SKALTSOUNIS, A.L. Development of a green extraction procedure with super/subcritical fluids to produce extracts enriched in oleuropein from olive leaves. The Journal of Supercritical Fluids, v.67, p.89-93, 2012.

ZHANG, Y.B., GUO, P.J., BAI, Z.Q. Tibetan Medicines in China. Shanghai Science \& Technology Press, Shanghai. 1996. 